\title{
A PRELIMINARY INVESTIGATION OF HIGHBUSH BLUEBERRY PEST AND DISEASE CONTROL
}

\author{
A.R. TOMKINS and M.S. KOLLER
}

Ruakura Soil and Plant Research Station, MAF, Private Bag, Hamilton

\section{SUMMARY}

Causes of fruit rejection on sprayed and unsprayed highbush (Vaccinium corymbosum) blueberries were determined at Moanatuatua Research Station.

On unsprayed bushes $4.8 \%$ of fruit was unsuitable for export. This was reduced to $3.4 \%$ by regular spraying. On unsprayed bushes, fruit rejection was caused by the following pests in decreasing order of importance; spiders, grass grub (Costelytra zealandica) beetles, leaf roller (Tortricidae sp.) larvae, case moth (Liothula omnivorus) caterpillars, Katydid (Caedicia simplex) nymphs and adults, mealy bug (Pseudococcus sp.), psocids, greedy scale (Hemiberlesia rapax), Stathmopoda sp. larvae and tydeid mites (Tydeus californicus). Wind rub and Botrytis infection were the major causes of fruit rejection.

\section{INTRODUCTION}

The New Zealand highbush blueberry industry centred in the Waikato, has expanded rapidly over the last decade (Wood and Poll 1985). As production is strongly export-orientated, high quality fruit is required. A key factor in fruit quality is efficient pest and disease control.

The New Zealand blueberry crop is not subject to attack by specific pests found in USA (Anon 1973). In fact, Van der Elst (1978) suspected that no pest and disease control programme was required to produce fruit for consumption in N.Z. However, export crops must be free from damage and contamination. Some orchards have suffered serious damage by grass grub beetles (East and Holland 1984) and crops have been contaminated by tydeid mites (Baker 1983).

Information does not exist on the relative importance of the pests and diseases affecting the New Zealand blueberry crop and the effectiveness of the current MAF spray programme. This paper details some initial observations in these areas.

\section{Trial areas and treatments}

\section{METHOD}

Observations were made on two 7 year-old plantings at Moanatuatua Research Station. Bushes were spaced at $1.8 \mathrm{~m}$ within and $3.6 \mathrm{~m}$ between rows. Blocks $\mathrm{A}$ and $\mathrm{B}$ had 42 and 48 bushes six of each cultivar 'A9', 'A16', 'C11', 'D14', 'Burlington', 'Dixi', 'Jersey', while block B also contained rabbiteye, Vaccinium ashei. The cultivars were in a randomised block design.

No pesticide treatments were made to block A. A trial comparing several spray programmes was conducted in block B. The two treatments reported here were unsprayed control and the 1984/85 MAF programme (minus miticides, benomyl and the pre-blossom insecticide spray) (Table 1). Each spray treatment was replicated six times with individual bushes as plots. Pesticide treatments were made to run-off with a motorised knapsack mist blower.

\section{Pest monitoring}

Leaf roller populations were monitored in block $\mathrm{A}$ with port wine bait traps from 23 August and weekly time searches of bushes from 7 November.

To determine the effect of spray programmes on tydeid mites, leaf samples were collected from block B at fortnightly intervals. Twenty mature leaves were taken at

Proc. 38th N.Z. Weed and Pest Control Conf. 
random per bush and held in sealed plastic bags until the mites were removed with a brushing machine and counted.

Damage assessment

To determine when fruit damage occurred, seven bunches of fruit, selected at random on each bush in block A, were tagged on 25 September. At 2-4 week intervals, bunches were inspected and the number of clean and blemished fruit recorded.

A quarter of the crop from each bush was harvested at weekly intervals as the fruit ripened. Up to the first 1000 fruit per bush from each pick, were examined for damage or contamination.

TABLE 1: Spray programme applied to highbush blueberries.

\begin{tabular}{llc}
\hline Application date & Chemical & Rate g ai/100 litres \\
\hline $3 / 10$ & iprodione (Roval 250 Fl) & 50 \\
$16 / 10,24 / 10$, & captan (Orthocide 80 WP) & 100 \\
$30 / 10,7 / 11$ & azinphos-methyl (Gusathion M50) & 50 \\
$22 / 11$ & captan & 100 \\
$6 / 12$ & methomyl (Lannate 20 NAC) & 24 \\
$14 / 12,23 / 12$ & captan + methomyl & $100+24$ \\
$5 / 1$ & captan & 100 \\
$17 / 1$ & methomyl & 24 \\
$1 / 2$ & &
\end{tabular}

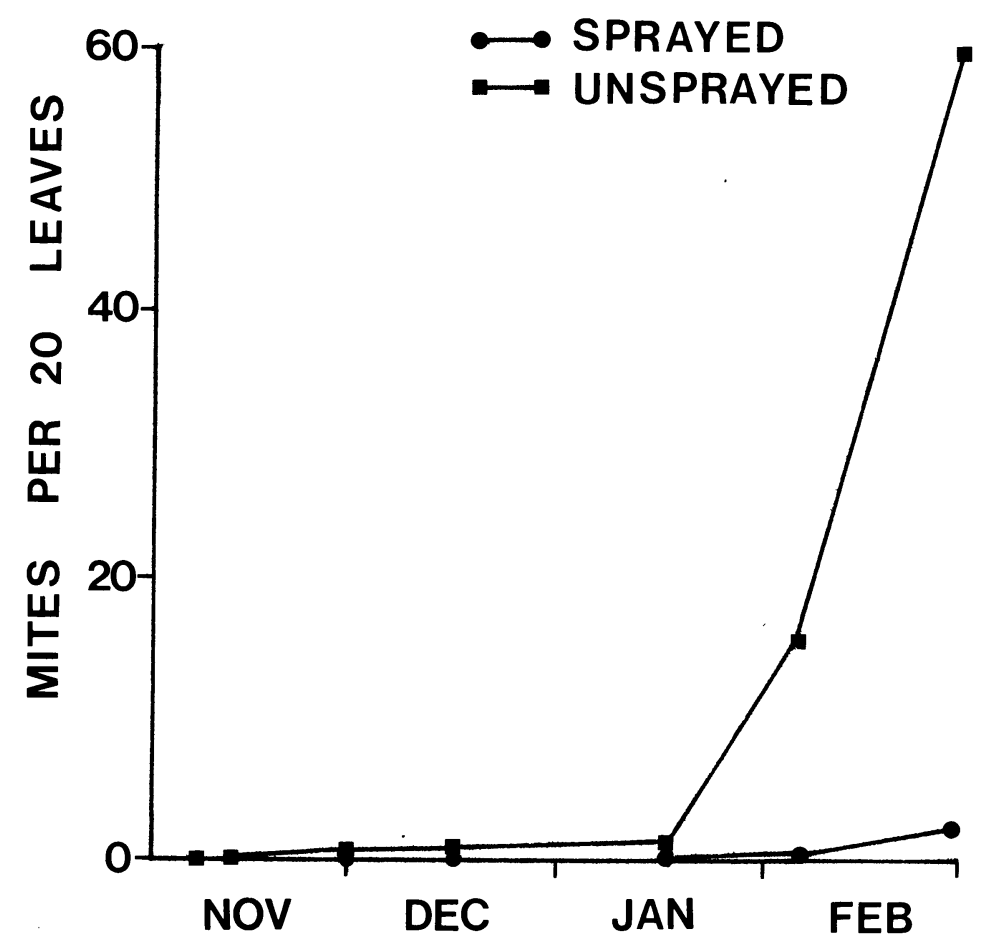

Fig. 1: Number of tydeid mite (Tydeus californicus) adults plus nymphs found per 20 leaves on unsprayed or regularly sprayed highbush blueberries. 
Crop phenology

\section{RESULTS AND DISCUSSION}

The first insecticide application in the MAF spray programme should be applied immediately pre-blossom. Depending on the cultivar, flowering began at Moanatuatua in mid September and continued until early November. Flowering and fruit set were prolonged, the latter beginning in late September. After fruit set, most of the fruit reached maturity. Fruit drop did not cause major losses of fruit damaged early in the season.

\section{Insect phenology}

In the Waikato, the first leaf roller flights begin in September (light brown apple moth, LBAM, Epiphyas postivittana), or late October (Ctenopseustis obliquana, Planotortrix excessana). Oviposition on the blueberry plants began in early November as a hatched LBAM egg batch was found on 27 November. Second flights of all three species began in mid January (Verberne et al 1985) when most of the blueberry crop had been harvested.

Tydeid mites were found from 14 November, but only in small numbers until late January (Figure 1). A similar trend has been observed on commercial blueberry plantings in the Waikato (P.T. Holland pers. comm.).

Crop damage and contamination

Only $4.8 \%$ of the unsprayed crop in block B was unsuitable for export. Details of the fruit rejected because of pests, diseases and physical damage are given in Table 2. The lack of pest damage may be due to several factors. As insecticide treatments had not been used on the bushes previously (J. Poll pers. comm.) parasite numbers had probably built up. More importantly, peat districts such as Moanatuatua have fewer alternative pest host plants thereby reducing sources of infestation. The MAF programme reduced pest damage and lowered the fruit rejection rate to $3.4 \%$.

TABLE 2: Major causes of imperfection in highbush blueberries harvested at Moanatuatua Research Station 1985.

\begin{tabular}{|c|c|c|c|c|c|c|c|}
\hline \multirow[t]{2}{*}{ Treatment } & \multicolumn{7}{|c|}{ Pest Cause (\%) } \\
\hline & Spider & $\begin{array}{l}\text { Grass } \\
\text { grub }\end{array}$ & $\begin{array}{l}\text { Leaf } \\
\text { roller }\end{array}$ & Pests & Katydid & $\begin{array}{c}\text { Mealy } \\
\text { bug }\end{array}$ & $\begin{array}{l}\text { Other } \\
\text { pests }\end{array}$ \\
\hline \multirow{4}{*}{$\begin{array}{l}\text { Unsprayed } \\
\text { Sprayed }\end{array}$} & 19.8 & 10.9 & 9.4 & 6.0 & 3.0 & 1.2 & 5.8 \\
\hline & 5.6 & 13.6 & 3.5 & 4.3 & 2.5 & 0 & 0.1 \\
\hline & \multicolumn{7}{|c|}{ Diseases/physical/physiological causes $(\%)$} \\
\hline & \multicolumn{2}{|c|}{ Botrytis } & \multicolumn{2}{|c|}{ Rub } & Malformed & \multicolumn{2}{|c|}{ Imperfect } \\
\hline Unsprayed & \multicolumn{2}{|c|}{20.1} & \multicolumn{2}{|c|}{23.4} & 0.5 & \multicolumn{2}{|r|}{4.8} \\
\hline Sprayed & \multicolumn{2}{|c|}{25.9} & \multicolumn{2}{|c|}{41.7} & 2.8 & \multicolumn{2}{|r|}{3.4} \\
\hline
\end{tabular}

The major pests of unsprayed blueberries in descending order were: spiders, grass grub beetles, case moth caterpillars, katydid adults and nymphs and mealy bugs. Spiders contaminate fruit with their webbing which requires additional grading or rejection. Grass grub damage was much less than the levels of 20 to $40 \%$ of the total crop commonly observed for bushes growing on mineral soils (East and Holland 1984; R. East pers. comm.). Case moth larval feeding produced small depressions on fruit, whereas katydids removed patches of skin from ripe fruit. Amongst the other pests found were psocids, greedy scale, tydeid mites and Stathmopoda larvae. Dead fruit which had failed to set or been killed by Botrytis infection were favoured feeding sites for Stathmopoda larvae. Occasionally they were found on fresh fruit as well.

Pest damage was less important than Botrytis infection and rub. Rub was the most important cause of fruit rejection and mainly arose from low branches touching the soil. Botrytis infection occurred from flowering onwards. Many of the fruit infected during flowering failed to develop but some matured. These latter fruit were distinguished at harvest by depressions radiating from the calyx end of fruit. Latent infections developing post-harvest were not evaluated. 
TABLE 3: Size and percentage of unsprayed blueberry bunches damaged by leaf roller larvae.

\begin{tabular}{lcccrr}
\hline & \multicolumn{5}{c}{ Date } \\
& $25 / 9$ & $31 / 10$ & $14 / 11$ & $27 / 11$ & $14 / 12$ \\
\hline \% bunches damaged & 2.0 & 4.0 & 14.4 & 8.1 & 6.4 \\
Mean No. fruit/bunch & - & 78.3 & 76.0 & 75.4 & 73.0 \\
\hline
\end{tabular}

The omission of the first insecticide treatment from the MAF programme (preblossom) may have resulted in inadequate protection from leaf roller. Damage of leaf roller larvae (mainly LBAM) began at flowering (Table 3) when larvae which had overwintered on the bushes inside buds, emerged to attack developing leaves, flowers and fruitlets. Overwintering larvae continued to damage fruitlets up until mid November. Damaged fruitlets were often hollowed out, but some still managed to reach maturity. An application of one or two insecticide sprays after harvest to coincide with the third leaf roller flights should prevent this type of fruit damage in the following season. The effects of first generation larvae were first noticed in mid December when fruit were contaminated by a few third instar larvae webbing up inside fruit calyces. Fruit damage increased in late December. Prevention of fruit contamination by first generation leaf roller larvae in early December should be the main aim of the spray programme.

Very few fruit were found to be contaminated by tydeid mites. Although no miticides were applied, the pesticides used in the MAF programme did reduce the tydeid mite numbers on the leaves (Figure 1). As the mite populations did not build up until late January, this pest should not be a problem except for late cultivars and where there is a large resident population. For example, willow weed (Polygonum persicaria), an alternative tydeid mite host growing beneath blueberry bushes has led to serious fruit contamination by tydeid mites.

In conclusion, the MAF programme ensures adequate pest control except for spiders and grass grub beetles. Some adjustments to the materials or times of application used for Botrytis control may however be necessary.

\section{ACKNOWLEDGEMENTS}

The authors gratefully acknowledge the technical assistance of Ms G. Sands and the various persons who helped harvest the crop.

\section{REFERENCES}

Anonymous, 1973. Commercial blueberry growing. U.S.D.A. Farmers Bulletin 2254 $31 \mathrm{p}$.

Baker, R.T., 1983. New mite threat to blueberries. Hort. News 4(10): 16.

East, R. and Holland, P.T., 1984. Control of grass grub beetles in blueberries. Proc 37th N.Z. Weed and Pest Control Conf.: 228-230.

Van der Elst, F.H., 1978. Research on propagation and establishment of blueberries at Ruakura Research Centre. Proc. Blueberry Field Day, Awakeri, Bay of Plenty. pp 1-29.

Verberne, H., Tomkins, A.R. and East, R., 1985. Blueberry pests and diseases. Ruakura Hort. Conf. (Blueberries): 19-23.

Wood, F.H. and Poll, J.T.K., 1985. Blueberry cultivars: production and quality. Ruakura Hort. Conf. (Blueberries): 1-7. 